\title{
Analysis of ECOWAS Institutional Framework for Conflict Management
}

\author{
Odobo, Samuel Osagie ${ }^{1}$ \\ Andekin, Amos Musa ${ }^{1}$ \\ Udegbunam, Kingsley ${ }^{2}$ \\ ${ }^{1}$ Institute for Peace and Strategic Studies, \\ University of Ibadan, Ibadan-Nigeria \\ ${ }^{2}$ University of Nigeria, Nsuka, Enugu-Nigeria
}

Doi: 10.1515/mjss-2017-0051

\begin{abstract}
The Economic Community of West African States (ECOWAS) has evolved conflict management and security framework through which it responds to the myriads of socio-political crisis in the sub-region. This paper assesses the ECOWAS mechanisms for conflict management vis-à-vis the challenges facing the region. It begins by looking at the nature of conflict in West Africa; and then the evolution of ECOWAS conflict management framework. Using content analysis, the paper argues that ECOWAS has evolved a comprehensive conflict management and security framework and has made significant achievements in conflict management in the West African sub-region. It however, recommends peacebuilding efforts that address poverty, human rights abuses and election fraud as well as more synergy and political will to handle religious extremism in the sub-region.
\end{abstract}

Keywords: ECOWAS, conflict, security, conflict management framework, West Africa

\section{Introduction}

The mantra of African solution to African problem gained greater currency in the years following the end of the Cold War (Albert, 2011). Before then, major happenings in the African continent were mired in the Cold War politics between the Soviet Union and the United States. During this period, African governments and rebel groups alike enjoyed the backing and support of the ideologically polarized super powers that were bent on undoing each other. Economic, financial, social and political aids flowed into the continent time and again as the US and the Soviet Union jostled to protect their strategic interests in the region. But with the end of the Cold War, the African continent was arguably left to fend for itself.

The US, obviously the only super power remaining, in conjunction with other Western powers diverted their attention to Eastern Europe where former Soviet States were beginning to embrace capitalism. While the world celebrated the new found post-Cold War peace, many countries in Africa descended into armed conflict. The emergence of violent hostilities in the 1990s can be attributed to the withdrawal of super powers' strategic interest in Africa following the end of the Cold War. The intensity and carnage that attended these conflicts, coupled with the inactions of the "big powers", reinforced the need for an African solution to what was largely considered as an African problem. This necessitated sub-regional organizations such as the ECOWAS to intervene in countries such as Liberia, Sierra Leone, Guinea and Ivory Coast through its intervention forceECOWAS Cease-Fire Monitoring Group (ECOMOG). 
Ever since, ECOWAS have developed elaborate conflict management frameworks in dealing with the challenges confronting the sub-region. Though this is a bold attempt by an African institution to address problematic situations in the sub-region, the ECOWAS conflict management framework and its application have been marred by several challenges. For example, ECOWAS interventions have been characterized by a host of controversies including lack of United Nations Security Council authorization to enforce peace, weakness in decision making, accusations of hegemony by Nigeria, and so on. In addition, because of the dynamic nature of conflict in the region, there is need for a reassessment of established frameworks to be able to meet up with new and emerging challenges.

This paper assesses the ECOWAS mechanism for conflict management vis-à-vis the challenges facing the region. It begins by looking at the nature of conflicts in West Africa, and then evolution of ECOWAS conflict management framework. It concludes by assessing its operational experience in conflict management.

\section{The Nature of Conflict in West Africa}

There is a rich body of literature on the causes of conflict in Africa. While it is true that Africa's wars in general are the result of a mixture of structural economic, political, cultural and historical factors (Bakut, 2009; Edlyne, 2009; Osaghea, 2005; Albert, 2003; Bozeman, 1976). The root causes of conflicts in Africa are usually traceable to the colonial era when Europeans scrambled for territories with scant regard for ethnic boundaries (Richard, 2006). There is hardly any zone within the continent that cannot trace its conflict and instability to its colonial history. European colonialism along with its attendant historical legacies played a key role in causing, sustaining and aggravating all types of conflicts through the creation of artificial colonial boundaries, which led to state formations, but with little or no regard for ethnic and cultural identities that existed prior to their incursion into African territory. Other causes of conflict in Africa include military incursion into governance, ethnic deprivation, poor governance and ecological and environmental problems.

The West African sub-region is not a homogenous zone. The region is made up of a variety of states in terms of territorial size, colonial history, economic strength, internal cohesion and external linkages. It comprises eight francophone countries (Benin, Burkina Faso, Cote d'Ivoire, Guinea, Mali, Niger, Senegal and Togo); five Anglophone countries (Gambia, Ghana, Liberia, Nigeria and Sierra Leone); and two Lusophone states (Cape Verde and Guinea Bissau).

The defining features of this region are corruption, poverty, underdevelopment, political instability, electoral violence, arms proliferation, and military incursion in governance; drug trafficking, territorial disputes; problem of leadership, resurgence of religion and ethno-religious conflict, secessionist tendencies, and inability of the states to provide and/or guarantee security for the people. The most problematic area in the sub region has been the Mano River Region, comprising Liberia, Sierra Leone and Guinea, renowned for prolonged internecine wars (Odobo, 2011). Besides, Ghana and Cote d'Ivoire reputed as citadels of political stability, have also had their fair share of internal political divisions; while Guinea, Nigeria and Mali have also experienced one form of instability or the other (Oloyede and Albert, 2010).

Hence, while it can be argued that states in the West African sub-region are not homogeneous in terms of seize and endowment, they do have in common, cross-cutting features of insecurity associated with poverty, underdevelopment, conflict and crime both at the national and transnational levels with far-reaching implications. The point of emphasis is that the inability of many West African states to effectively secure the nation and manage domestic pressures has resulted to violent conflicts beginning with Liberia in 1989, Sierra Leone in 1991 and so on (Udofia, 2010). The neighborhood effect of the conflict and the reluctance of the international community especially the "big powers", compelled some regional leaders within ECOWAS to push for intervention in Liberia, and ECOWAS through its intervention force intervened to deal with the crises. This was a watershed in terms of sub-regional intervention in internal conflict despite the fact that ECOWAS was not originally established to perform conflict management role. 


\section{Evolution of ECOWAS Conflict Management and Security Role}

ECOWAS was established on May 28, 1975 primarily to achieve an economic union. It was not originally designed to perform security role; its mandate was to promote trade, cooperation and economic development among its member states (ECOWAS, 1993). However, it was inevitable that the organization will perform this task given the incessant security challenges that befell the subregion after its establishment such as the failed attempt in 1977 by some mercenary soldiers to over throw the government of the Republic of Benin allegedly sponsored by some African states; incessant border disputes and the problem of irredentism between Togo and Ghana, over the control of the Voltage Region; Togo's accusation of Ghana and Burkina Faso of interfering in her internal affairs by steering up internal uprising against its government; territorial dispute between Mali and Burkina Faso resulting in armed conflict between the countries in 1985 and so on (NIIA, 1985).

These disturbing events not only stifled ECOWAS' ability to pursue its economic development mandate, but led to serious deliberations on the need to ensure sub-regional security, stability, and peace. Consequently, ECOWAS adopted the Protocol on Non-aggression in 1978 and the Protocol on Mutual Assistance on Defence in 1981; two legal instruments that were meant to facilitate peace and political stability in the sub-region. The Protocol on Non-aggression directly addressed issues of inter-state conflicts within the sub-region and also promoted peaceful settlement of conflict between ECOWAS member states. The Mutual Assistance on Defence on the other hand called on ECOWAS member states to pull together their defense strategies at a regional level against threats of aggression within West Africa backed by external influences (Goldman, 2005).

Although the two instruments are commendable in their quest to promote peace in the subregion, they largely addressed conflicts arising from inter-state relations at a time when intra-state conflicts were fast escalating across the sub-region. These inadequacies and challenges necessitated a more comprehensive and encompassing conflict management framework that will address both intra and inter-states conflicts in the sub-region.

\section{ECOWAS Mechanism for Conflict Prevention, Management and Resolution, Peacekeeping and Security}

The genesis of the ECOWAS conflict mechanism can be found in the inadequacy of the previously existing Protocols to address with emerging security issues in the sub-region especially the conflicts in Liberia and Sierra Leone. Spillover effects of the conflicts had earlier led ECOWAS leaders to establish a Standing Mediation Committee (SMC) on May 9, 1990 which produced the ECOWAS Monitoring and Observation Group (ECOMOG) with a mandate to stabilize situations in both countries. Apart from the legality of ECOMOG intervention in Liberia being challenged, it encountered several challenges in its operations in what became a learning experiment for ECOWAS in sub-regional conflict management (Chikwem, 2007). Similar development in Guinea Bissau in the 1990s convinced ECOWAS that developing a mechanism for conflict management to address the shortcomings of the earlier protocols was important if sub-regional stability and development was to be realized.

The Protocol Establishing the Mechanism for Conflict Prevention, Management and Resolution, Peacekeeping and Security was adopted by the ECOWAS Authority of Heads of State and Government in Lome, December 10, 1999. The Mechanism institutionalized a framework that would ensure wide consultation and inclusiveness of relevant stakeholders in managing issues that affect sub-regional security. The framework included organs such as the Authority of Heads of State and Government, Mediation and Security Council, the Executive Secretariat, Council of Elders, Defence and Security Commission. Others include Early Warning Observation and Monitoring System while ECOMOG was also incorporated into the Mechanism.

\subsection{The Authority of Heads of State and Government}

The Authority of Heads of State and Government is the apex decision making body according to the 
Mechanism. However, Article 7 of the Treaty establishing the Mechanism gives the Authority the ability to delegate its powers to the Mediation and Security Council.

\subsection{The Executive Secretariat}

The body is saddled with the responsibility of daily administration of the organization. The head of the Secretariat is the Executive Secretary also regarded as the chief administrator of the Secretariat. However, the Secretariat was transformed into a Commission in January 2007. The ECOWAS Commission (as it is called) is headed by a President appointed by the Heads of State and Government of member states. He is also the Chief Executive Officer of the Community. The President of the Commission is assisted by a Vice and seven Commissioners. The headquarters is located in Abuja, Nigeria. The main task of the Commission is the promotion of socio-economic cooperation and political integration of member states.

\subsection{Mediation and Security Council}

The Council deliberates on all matters of peace and security on behalf of the Authority. It comprises nine member states out of which seven are elected by the Authority. The two other members are the incumbent chairman and the immediate past chairman of the Authority. Decisions in the Council are taken based on a two-third majority of votes. The Council officially took-off in May 2000 in Monrovia, Liberia (Bakhoum, 2010). The Council is a replica of the UN Security Council but it functions at a sub-regional level. It can meet at Ambassadorial, Ministerial or Heads of State and Government Levels.

While the Committee of Ambassadors (made up of ten elected Member States) meet every month to review matters of peace and security, the Committee of Ministers of Foreign Affairs, Defence, Internal Affairs and Security meet at least once in three months to deliberate on general political and security situation in the region. Furthermore, the ten member Heads of State and the Mediation and Security Council meet at least twice a year and they have the final decisions on the appropriate policies or measures to be taken with regards to decisions that have been reached by the Mediation and Security Council. It also requires a two-third majority of votes to take a position. The Mediation and Security Council superintends over the activities of lower organs such as Defence and Security Commission. Like the UN Security Council, it has the authority to authorize all forms of intervention such as ECOMOG intervention. It does this after due consultations with the UN and AU about its decisions and it also has the power to appoint ECOMOG Commanders and review the mandates of any mission.

\subsection{Defence and Security Commission}

This Commission is made up of the Chiefs of Defence Staff of Member States of ECOWAS. Its function is to assess all technical issues and review logistical requirement for any peacekeeping missions. It is also the Commission's job to assist the Mediation and Security Council in matters of organization and deployment of peacekeeping forces in the sub-region. Additionally, the body reviews reports from the various Observation and Monitoring Centres upon which it advises and recommends necessary steps to the Mediation and Security Council. Although the Commission meets once every three months, special sessions can be called when the need arises.

\subsection{Council of Elders}

The Council of Elders is constituted by the Executive Secretary to help the organization in the area of preventive diplomacy. The body is made up of eminent and prominent individuals especially past heads of state, renowned diplomats and religious leaders. They are called upon to utilize their good offices to intervene in conflicts and periods of political turbulence within or between member states as mediators, conciliators, or facilitators. The Council of Elders was inaugurated in July 2001 in Niger. They have also been involved in election monitoring in countries such as Gambia, Sierra 
Leone, and Togo as well as in countries outside the sub-region such as in Zimbabwe.

\subsection{Early Warning Observation and Monitoring System}

ECOWAS developed early warning system as part of its conflict prevention strategy. The Observation and Monitoring Centre (OMC) is the center of ECOWAS early warning system. ECOWAS partners with civil society actors such as the West African Network for Peace (WANEP) in order to enhance its data collection and analysis. However, civil societies only assist but have no presence in the decision-making structures. ECOWAS has four Observation and Monitoring Zones in West Africa coordinated by WANEP.

These four zones have their capitals in Gambia (Banjul), Liberia (Monrovia), Burkina Faso (Ouagadougou) and Benin Republic (Cotonou). The function of these zones is to collect data on potential causatives of disputes or conflict triggers. They monitor trends and occurrences that have implications for peace and security. These includes small arms and light weapons movements, youth restiveness, smuggling, ethnic/local militias and emergent rebel groups; and transmit same to the OMC hub at the headquarters in Abuja.

\subsection{ECOMOG}

Although ECOMOG existed before the Mechanism was established, it was incorporated into the new conflict management framework because it is seen as a useful tool for maintaining peace in the region. ECOMOG - largely an ad-hoc military force consisting of land, air and sea components - was established by ECOWAS member states as a response to security problems that accompanied the civil war in Liberia in 1990. ECOMOG's troops consist mainly of contingents from the armed forces of ECOWAS member states.

ECOMOG has a command structure headed the Force Commander. The position of the Force Commander is closely followed by those of the Deputy Force Commanders who are also commanders of the various troop contingents from their home countries. The Force Commander of ECOMOG with his planning staff coordinates the activities of the various contingents, and together with the contingent commanders deal with common problems arising in the region. The central planning office is responsible for designating responsibilities in the mission area to individual contingent commanders, after observing due diligence in terms of assessment of their strength, instruction from their home government as well as the level of equipment, arms and ammunition that they have (Mitikishe, 2000).

\section{Intervention}

The ECOWAS conflict management framework provides for regional intervention in the event of political crisis in members states. In fact, ECOMOG has been adopted as the regional intervention force. Intervention became popular in the 1990s when ECOWAS deployed ECOMOG forces in Liberia to prevent Charles Taylor-led National Patriotic Front of Liberia (NPFL) from overthrowing the government of Samuel Doe. ECOMOG intervention can take the form of peacekeeping or peace enforcement. It can also monitor ceasefire agreements, and when the conflict parties who signed the ceasefire fail to abide by the terms of the agreement, such violations are taken into consideration to determine whether there is need for ECOMOG to intervene and compel the uncooperating parties to respect the provisions of the ceasefire agreement. In other words, ECOMOG missions could change from peacekeeping to peace enforcement depending on the conditions on ground and it can again quickly convert from the latter to the former. Such was the case in Liberia and Sierra Leone where ECOMOG intervened as a peacekeeping force to protect government properties and civilian populations. The violence shown by the NPFL and the Revolutionary United Front (RUF) in both countries meant that intervention passed from peacekeeping to peace enforcement operation.

Apart from Liberia and Sierra Leone, ECOMOG missions have also been deployed in Guinea Bissau (1998) leading to a ceasefire on $20^{\text {th }}$ July 1998 followed by the Abuja peace agreement on 
November 1, 1998. It also intervened in Cote D'lvoire primarily to monitor the October 17, 2002 ceasefire agreement (Woods, 2003). ECOMICI (ECOWAS Mission in Cote D'Ivoire) was made up of about 1,400 troops deployed from Senegal, Ghana, Benin, Togo, and Niger under Force Commander, Major General Abdoulaye Fall (Mitikishe, 2000). Following the UN Security Council vote on February 282004 in favour of integrating $\mathrm{ECOMICl}$, the Mission was absorbed into the UN Operation in Cote D'Ivoire (UNOCI) which took effect from April 4, 2004.

\section{ECOWAS Protocol on Democracy and Good Governance}

With a view to strengthening the ECOWAS Mechanism which has become ECOWAS' foundational sub-regional security framework, ECOWAS leaders in 2001 signed the Protocol A/sp/1/12/01/ on Democracy and Good Governance supplementary to the protocol establishing the mechanism for conflict Prevention, Management and Resolution, Peacekeeping and Security. The Supplementary Protocol is viewed as a robust instrument that takes into account the underlying (political) triggers of instability, conflicts and insecurity in West African states which were largely overlooked by the ECOWAS Mechanism (Lar, 2009).

The protocol highlights the fundamental requirement for achieving democracy and peace in the sub-region with particular focus on respect for human rights, the rule of law, and government's commitment to delivering good governance, free, fair and credible elections. It also highlights the importance of election monitoring and ECOWAS' role in that regard. Additionally, it talks about the limited role that the armed forces, the police and other security formations have to play in a democracy. With regards to good governance and constitutional principles, it called for clear separation of powers between the three arms of government-Executive, Legislative and Judiciary; a guarantee of parliamentary independence and immunity; constitutional ascension to power; and the need for the armed forces to be apolitical and to be under the command of a legally constituted political authority. The Protocol also barred serving member of the armed forces from seeking elective political office. It recognized respect for freedom, civil and political rights as well as the importance of political parties to engage freely without encumbrances in all electoral processes. Importantly, the guarantee to the right of opposition is also stipulated (ECOWAS, 2001).

Another important provision on the protocol is that "a substantial electoral law cannot be changed without the consent of a large majority of political actors within the six months preceding the election" (ECOWAS, 2001). This perhaps is a response to the history of unconstitutional and undemocratic ascension to political power in the sub-region since the 1990s. Thus, ECOWAS has a duty under the protocol, to ensure that elections in member countries are smooth running, free, fair, honest, and transparent.

In addition, the protocol calls for member states to "eliminate all prejudicial, degrading and discriminating practices towards women, children and the youth" (ECOWAS, 2001). In other words, their well-being is proof of a democratic society that delivers development, economic prosperity and social peace. Basically, the whole goal of the protocol is to curb those factors that provoke crises and social instabilities which have been common in most cases of violent conflicts in the region over the years.

\section{ECOWAS Conflict Prevention Framework (ECPF)}

Problems relating to implementation of the preventive aspect of the 1999 Mechanism especially late response to crisis informed the establishment of the ECOWAS Conflict Prevention Framework (ECPF) in 2008. The goal of the conflict prevention framework is to ensure the creative transformation of conflict, diffusion of tensions and prevent conflict outbreak, escalation, spread or relapse. In other word, it involves institutionalizing measures to ensure that conflicts do not arise in the first place or if they do, that they do not reoccur. The emphasis according to the framework is not to prevent conflict per se (since conflict is a natural phenomenon), but to ensure that it does not escalate into violence. This involves identifying conflict triggers i.e. sudden events or accelerators that could spark a crisis which could in turn lead to violent conflict.

It can be argued that the ECPF is a proactive alternative to ECOMOG. Rather than wait for 
conflict to occur, escalate and become violent before intervention, the position should be to prevent the occurrence or recurrence of violent conflicts. This means that, military intervention should only constitute a measure of last resort. This would be done by initiating measures such as sustainable development and strengthening a culture of democracy and developmental reforms not only aimed at preventing socio-economic conditions from deteriorating, but also, actively pursuing peacebuilding in post-conflict countries over a period of time so as to forestall a relapse into conflict.

The ECPF has components such as Early Warning, Preventive Diplomacy, Human Rights and the Rule of Law, Media, Democracy and Political Governance, Women, Peace and Security, Natural Resources and Governance, Peace Education etc. Critical to the ECPF is the early warning component which is designed to help ECOWAS member states predict the emerging conflicts and facilitate interventions to avert, diffuse or creatively transform such potential or latent conflict situations. To achieve the early warning objectives, the ECOWAS Early Warning and Response Network (ECOWARN), was reinvigorated.

\section{Appraisal of ECOWAS Conflict Management Framework}

ECOWAS successfully transformed from being an economic body into an eco-political union and took upon itself the task to perform conflict management, peacebuilding and security stabilization functions in the West African sub-region. That the body has had a huge influence on the West African sub-region with regard to conflict management and conflict resolution cannot be disputed. However, what remains controversial is whether its institutional framework for dealing with conflict has yielded maximum impact. In other words, is the ECOWAS conflict management framework effective enough in managing the current conflict triggers facing the region today?

First, the ability or capacity for any organization including ECOWAS to undertake any security role can be found either in its constitutional provisions or the treaty establishing the body mandating that body to perform conflict management function or institutional mechanism through with such mandate can be exercised (Fanta, 2009). For ECOWAS, specific legal protocols have been adopted on how it intends to operate in peace and security affairs such as the Mechanism, the Democracy Protocol and the ECPF. However, the organization has neglected the need to adopt constitutional provision on these as the United Nations has done.

It can be argued that ECOWAS has a relatively comprehensive institutional mechanism for dealing with conflict. For example, its decision to establish a peace organ attests to the fact that the organization is committed to sustainable peace in the sub-region. Either operating under Chapter VI or Chapter VII of the UN Charter, ECOWAS has shown to have considerable experience in peacekeeping, peacemaking and peace enforcement as its intervention in Liberia (1990-1998; 2003); Sierra Leone (1997-2000); Guinea Bissau (1998-1999); Niger (2005-2010); Togo (20092010); Cote D'Ivoire (2002-2004, 2007, 2010-2011), and so on depicts. Arguably, ECOWAS has a clear mandate and a considerably strong organizational capacity for peacemaking, peacekeeping and peace enforcement.

At the level of conflict prevention, ECOWAS Protocol on Democracy and Good Governance prescribes measures urging its member countries to respect democratic principles which would go a long way to ensure that unwanted conflicts do not arise. Although these measures have not entirely eliminated the problem of bad governance, coups and so on, they have helped to reduce threats to democratic governance and the negatives it can have on the sub-region. The ECPF is another good example of ECOWAS efforts to prevent conflict and promote regional stability. A central part of the ECPF is the recognition that development, peace, security, and democratic governance are fundamental to the development of the ECOWAS region. A crucial objective of the framework is to prevent the outbreak of violent conflict.

In 2005, political events in Togo challenged the ECOWAS Protocol on Democracy. ECOWAS responded positively; unconstitutional ascension to power of Faure Eyadema was strongly condemned by ECOWAS. Togo was sanctioned, and suspended from participating in the ECOWAS activities; ECOWAS also placed travel ban on its leaders as well as imposition of arms embargo against the country (Clayton, 2005). ECOWAS' hard diplomacy paid off, Faure resigned as interim President of Togo. Presidential elections were conducted. However, to the disappointment of many, 
Faure Eyadema won about $60 \%$ of the total votes cast and was elected president (Levit, 2010). Whatever the case, the threat of instability in the country was effectively reversed by the ECOWAS in a peaceful and non-violent manner.

Fanta (2009) is of the view that ECOWAS remains at the forefront in terms of early warning. ECOWAS has worked with Civil Societies to establish four early warning bureaus in Banjul, Ouagadougou, Monrovia, and Cotonou (ECOWARN, 2008). Notwithstanding, ECOWAS early warning system (ECOWARN) has faced certain challenges. ECOWAS lacks the necessary human and material resources to effectively cover a vast region as West Africa with its enormous problems associated with underdevelopment, poverty, electoral and political violence and the general issues of human security. ECOWAS requires a robust staff capacity at local, national and sub-regional levels to effectively collect information and report on developing or emergent conflict triggers.

Although ECOWARN has engaged the services of local capacities such as NGOS, women and youth associations, traditional institutions, intelligence agencies, the police and religious rulers, and so on, its capacities are still limited. In addition, deficiency in governance is still affecting its capacities for early warning systems. For example, Souare (2007:106) points to this deficiency of governance among ECOWAS member states:

\begin{abstract}
...it is not clear whether these zonal bureaus (of the ECOWAS EWR System) will be able to achieve their intended goals under the current regimes of observation and monitoring systems. It is unlikely that civil servants loyal to an undemocratic regime will be able to effectively monitor and report human rights situations, press freedoms and civil military relations in their countries or its allies.
\end{abstract}

Usually, governments are quite abreast through intelligence reports of emerging conflicts. Not only that, they themselves are sometimes the cause of these conflicts. They do not need any advanced early warning pointers to draw their attention to emerging conflict situations. Also, such governments are usually reluctant to acknowledge the fact that their poor human rights records are documented as constituting conflict indicators and the need to address them. Thus, despite recognizing the EWR system, they only pay lip service to it. It is argued by Barnett \& Bruce (2007:391) that in certain instances, some of these governments deliberately ensure that the relevant regional bodies remain weakened in their ability to collect data on early warning signals, thus preventing early response.

It can be argued that ECOWAS has performed better in crises management especially through the deployment of ECOMOG than in the area of conflict prevention. Notwithstanding, the organization has also recorded considerable success in conflict mediation and peacemaking. Through diplomatic maneuvering, ECOWAS has been able to arrange a number of ceasefires between hostile parties and ensure some level of compliance through the employment of peacekeeping forces.

In Guinea Bissau (1998), ECOWAS mediation efforts resulted in a truce between President Vieira and the rebel leader, General Mane. Similarly, its intervention in Sierra Leone secured the Abuja Ceasefire Accord. This agreement subsequently led to the Abuja meeting in May 2001 where both the RUF and the Sierra Leonean government committed to the disarmament process. In 2002, ECOWAS also dispatched a high-level ministerial delegation to Abidjan, Cote d'Ivoire to mediate between Laurent Gbagbo's government and rebel leaders in order to restore peace to the troubled country. Furthermore, ECOWAS also played a crucial role in 2003 in terms of de-escalating tensions between Senegal and Gambia over the disputes in Casamance (N'Diaye, 2007).

According to a UNOWA (UN Office for West Africa) report, "ECOWAS mediation has led to the signing of nearly two dozen peace agreements to end destructive conflicts in West Africa". Even at that, it is argued that the organization has not even fully exploited the potentials of its Council of Elders. Particularly, Fanta (2009) is of the view that some members of the body still do not have the required training and skills in conflict mediation and management.

Arguably, within the African continent, ECOWAS is considerably ahead of others in terms of experience in military deployment by a sub-regional organization. ECOWAS has effectively used peacekeeping and peace enforcement forces, including threat, imposition of sanctions and deployment of ECOMOG in the management of a number of conflicts. In spite of ECOWAS 
operational experience in peacekeeping and peace enforcement, a critical analysis shows specific weaknesses exist which include: the lack of a united command and control structure, as members states still retain considerable national control over their contingents; clear differences in capacity, capability, and professionalism of contingents; lack of a central logistics system; absence of capacity in logistics support; and lack of capacity in transition from a Peacekeeping mission to Peace enforcement as the Sierra Leone example demonstrated (Levit, 2010).

Some ECOWAS deployment (otherwise known as ECOMOG Missions) include: Liberia (19901997; 2003); Sierra Leone (1997-1999); Guinea Bissau (1998-1999); and Cote d'Ivoire (20032004). In all of these missions, ECOWAS failed to transit from peacekeeping to peace building. In each case, its troops were incorporated within the subsequent U.N mandate operations. ECOWAS incapacity to cope with the degenerating nature of the conflict in Guinea (1998-1999), led to withdrawal of its forces before the conflict was resolved (Fanta, 2009).

At the level of peacebuilding especially when viewed from the perspective of post-conflict reconstruction, reconciliation and rehabilitation, ECOWAS has not done enough. Establishing and maintaining ceasefires are important by themselves, they do not constitute successful management of conflicts. Success can be claimed when underlying issues in a dispute have been effectively resolved to the mutual satisfaction of the parties. ECOWAS has shown to be particularly weak in this regard. ECOWAS peacebuilding activities have been centered on election observation which is only one aspect of a comprehensive peacebuilding framework which must include, respect for human right and rule of law, imbibing the culture of strict adherence to democratic principles, civil service reforms, security sector reforms (SSR), reforms of the judiciary and properly addressing the root causes of the conflict, these reforms must also be adequately implemented (Fanta, 2009).

\section{Result and Conclusion}

In terms of general assessment of the performance of ECOWAS conflict management framework, significant achievement has been made by ECOWAS in conflict management. The fact that the ECOWAS sub-region has been transformed from a zone of crippling wars (especially in the Mano River Region) in the 1990s into an area where no active war is raging today is a mark of progress that has been made. At the same time, it can be argued that democratic culture is gradually taking root in many of ECOWAS member states. Both Liberia and Sierra Leone, two of the most disturbing and unstable states in West Africa have successfully conducted consecutive general elections. So too have some other ECOWAS member countries including Nigeria, Ghana and Senegal. Comparatively, ECOWAS has recorded more successes in the area of crisis management and has become a reference point in the African continent.

It can be said that with every threat to regional security, ECOWAS has shown commendable improvement in terms of capacity for quick and early response. Its experience in Liberia and Sierra Leone were an important learning curve which prepared the ECOWAS for future conflict diplomacy. For example, ECOWAS displayed its capacity to manage the crises in Guinea Bissau in 2003 and Togo in 2005.

However, ECOWAS can be said not to have performed too well in terms of response to the blatant disregard of its democratic principles by President Laurent Gbagbo of Ivory Coast who refused to step down after his opponent Allasane Quattara was declared winner of the November 28, 2010 elections. Although ECOWAS on more than one occasion sent special envoys to Cote d'Ivoire on the matter and had also threatened to use force to remove Gbagbo, the President defied all efforts by the ECOWAS to uphold democracy and the legitimate will of the Ivorian people. The organization could only call on the United Nations to beef up its resolve against Gbagbo. Nonetheless, this shortcoming is being corrected by the organization with regard to the crisis in Mali.

On a general note, there have been renewed cases of political instability in some of its member countries such as Nigeria (2015) and the Gambia (2016). These challenges are not unconnected with the process of democratization in the sub-region; including problems relating to governance, electoral reforms the rule of law; problems of leadership, corruption, hunger and poverty and so on. The corollary of these has been resurgence of religion, military intervention in 
politics, and secessionist groups. Islamic terrorism is fast sweeping across West Africa typified by the Boko Haram in Nigeria, ethno-political crises in Northern Mali, Mauritania, and Niger in a complex web linked to the ethnic Tuaregs across these countries and so on. These crises have become major problem that not only threaten the security and stability of the country involved but also that of other countries in the sub-region especially neighbouring countries. These could be considered as early warning signs which challenge ECOWAS to develop a robust framework to address if it is to avoid full blown conflicts across the sub-region with the potential to hamper its goal of sustainable peace and development.

\section{Acknowledgements}

The authors declare that this study was not sponsored by either an individual or groups and therefore the findings were not influenced in anyway whatsoever.

\section{References}

Adedeji, E. (2010). Towards a common ECOWAS agenda on security sector reform. [Online] Available: www.usip.org (November, 3, 2011).

Albert, I. O. (2003). Mainstreaming positive leadership in conflict transformation in Nigeria. Lagos: Center for Social Science Research and Development.

Albert, I. O. (2011). Pinched, ditched or jinxed? The mantra of African solutions to African problems. Inaugural Lecture delivered at the University of Ibadan, Nigeria. February 3, 2011.

Bakhoum, H. (2010). ECOWAS as a regional peace broker. [Online] Available: http://www.parl.eco.int (November 3, 2011.

Bakut, B. (2009). The environment, peace and conflict in Africa. In S. G. Best (Ed.), Introduction to peace and conflict studies in West Africa (pp. 234-251). Ibadan: Spectrum Books Limited.

Rubin, B. \& Jones, B. D. (2007). Prevention of violent conflict: Tasks and challenges for the United Nations. Global Governance 13 (3): 391-408.

Bozeman, A. B. (1976). Conflict in Africa: Concepts and realities. Princeton: Princeton University Press.

Chikwem, R. (2007). Why ECOMOG is still the best: The success and failure of ECOMOG peace operations. [Online] Available: https://dawodu.com/chikwem2.htm (January 26, 2011).

Clayton, J. (2005). Togo 'military coup' hands leadership to President's son. Times, (UK), February 7, 2005.

Wulf, H. \& Debiel, T. (2009). Conflict early warning and response mechanisms: Tools for enhancing the effectiveness of regional organizations? A comparative study of the A.U, ECOWAS, IGAD, ASEAN/ARF and PIF. Crisis States Working Papers Series, No.2. Destin Development Studies Institute.

ECOWARN (2008). Mid-year evaluation and update of ECOWARN. [Online] Available: http://www.wanep.org/ecowarn-update-o8.htm (January 26, 2011).

ECOWAS (1999). Protocol Relating to the Mechanism for Conflict Prevention Management, Resolution, Peacekeeping and Security. [Online] Available: http://www.zif-berlin.org/fileadmin/uploads/analyse /dokumente/ECOWAS_Protocol_ConflictPrevention.pdf (January 26, 2011).

ECOWAS (2001). Protocol A/SPI/12/01 On Democracy and Good Governance Supplementary to the Protocol Relating to the Mechanism for Conflict Prevention, Management. [Online] Available: http://www.comm.ecowas.int/sec/en/protocoles/Protocol\%20on\%20good-governance-and-democracy-rev5EN.pdf (January 26, 2011).

ECOWAS (1993). ECOWAS Revised Treaty, Chapter 2, Articles 3 (1993). Abuja: ECOWAS Executive Secretariat.

ECPF (2008). The ECOWAS Conflict Management Framework, Regulation M.Sc/REG.1/01/08. [Online] Available: http://www.ecowas.int/publications/en/framework/ECPF_final.pdf (January 26, 2011).

Anugwom, E. E. (2009). Theories of social conflicts. In M. Ikejiani-Clark (Ed.), Peace studies and conflict resolution in Nigeria: A reader (pp. 142-158). Ibadan: Spectrum Books Limited.

Fanta, E. (2009). The capacity of African regional organizations on peace and security. A paper presented at the ERD workshop on "transforming political structures, security institutions and regional integration mechanism". Florence, $16-17$, April.

Fawole, A. (2003). Nigeria's external relations and foreign policy under military rule, 1966-1999. Ife: Obafemi Awolowo University Press Ltd.

Furley, O. (1995). Introduction: The habit of conflict. In O. Furley (Ed.), Conflict in Africa. London: Tauris Academic Studies. 
Goldman, M. (2005). Sierra Leone: African solutions to African problems? In A. V. Bogdandy, W. Rudiger \& P. E. Christiane (Eds.), Max Planck yearbook of the United Nations law. (Volume 9). The Netherlands: Koninklike Brill.

Lar, J. T. (2009). The ECOWAS SSR agenda in West Africa: Looking beyond normative frameworks. KAIPTC occasional paper, No. 24, October, 2009, Accra, Ghana.

Levit, J. (2010). Pro-democracy intervention in Africa. Wisconsin International Law Journal, 24 (3): 785-833.

Mitikishe, M. K. (2000). The evolution and conduct of ECOMOG operations in West Africa. [Online] Available: http://web.archive.org/web/20060206083957/www.iss.co.za/Pubs/Monographs/No44/ECOMOG.html (January 26, 2011).

N'Diaye, B. (2007). The state in Cote d'Ivoire: Evolution and constraints. In P. Agbese \& G. Kieh (Eds.), Reconstructing the state of Africa (pp. 75-104). New York: Palgrave Macmillan.

Nigeria's Treaties in Force (1990). A/SP3/5/81 Protocol Relating to Mutual Assistance on Defence, done at Freetown, 29th May, 1981. Lagos: Federal Ministry of Justice.

NIIA (1991). Nigeria and the ECOWAS since 1985. Enugu: Fourth Dimension Publishing Co. Ltd/Federal Ministry of External Affairs, Nigeria.

Odobo, S. O. (2011). Comparative analysis of the conflict management frameworks in IGAD and ECOWAS. M. A. dissertation, Peace and Conflict Studies Programme, Institute of African Studies, University of Ibadan.

Oloyede, O. \& Albert, I. O. (Eds.), (2010). Dynamics of peace processes. Ibadan: John Archers.

Osaghae, E. E. (2005). Violence in Africa: State, ethnic and regional dimensions. In I. O. Albert (Ed.), Perspectives on peace and conflict in Africa (pp. 101-122). Ibadan: John Archers.

Richard, J. (2006). African wars: Overview, causes and the challenges of conflict transformation. In O. Furley \& R. May (Eds.), Ending Africa's wars: Progressing to peace (pp. 15-29). Ashgate: Aldershot and Burlington VT.

Souare, I. (2007). Conflict prevention and early warning mechanisms in West Africa: A critical assessment of progress. African Security Review, 16 (3): 97-109.

Udofia, D. (2010). Interrogating security sector reforms in West Africa. In I. O. Albert \& O. Oloyede (Eds.), Dynamics of peace processes (218-236). Ibadan: John Archers

Dwayne, W. (2003). The tragedy of the cocoa pod: Rent-seeking, land and ethnic conflict in Ivory Coast. Journal of Modern Africa Studies 41 (4): 641-655. 